\title{
STUDYING THE DETERMINANTS OF INTENTION TO USE TOKOPEDIA FOR SMES AGRIBUSINESS PRODUCTS PURCHASE
}

\author{
Lufebrina Dorma Uli Manalu*)1, Irman Hermadi**), and Joko Ratono $\left.{ }^{* * *}\right)$ \\ *) PT Bank Rakyat Indonesia (Persero) Tbk. \\ Jl. RM. Harsono No.2, Ragunan, South Jakarta, 12550 \\ **) Department of Computer Science, Faculty of Economics and Management, IPB University \\ Jl. Meranti, IPB Darmaga Campus, Bogor 16680 \\ ${ }^{* * *)}$ School of Business, IPB University \\ Jl. Raya Pajajaran, Bogor 16151
}

\begin{abstract}
Toko Laurike located in Bogor Regency, is a member of the small-medium enterprises (SMEs) group. It produces Virgin Coconut Oil (VCO) and sells its products through several e-marketplaces, namely Tokopedia, Bukalapak, and Elevenia. Among these e-marketplaces, Tokopedia sells product from Toko Laurike more than Bukalapak or Elevenia. This research aims to examine the factors that determine Consumers' intention to use of Tokopedia specifically for SMEs' food agribusiness products in the form of liquid and gel. This research also analyzed the pattern of design and security perceived ease of use and perceived usefulness. The other purpose is analyzing the contribution of security, perceived ease of use, perceived usefulness on consumers' intention to use. Data analysis tool using structural equation modeling - partial least squares (SEM-PLS) based on stimulus theoretical framework technology acceptance model (STF-TAM). The study involved Tokopedia's users who making purchasing for SMEs food agribusiness products in the form of liquid and gel. The 71 samples were collected. The results showed that perceived ease of use is most influencer among these factors. Design and security associated with perceived ease of use. Security was not associated with consumers' intention to use. The result can be used by Laurike to enhance e-commerce performance.
\end{abstract}

Keywords: Laurike's e-commerce, SMEs, SEM-PLS, STF-TAM, Tokopedia

\begin{abstract}
Abstrak: Toko Laurike adalah salah satu anggota Usaha Kecil Menengah (UKM) Pemerintah Kabupaten Bogor. Toko Laurike memproduksi Virgin Coconut Oil (VCO) dan menjualnya melalui pasar online yaitu Tokopedia, Bukalapak dan Elevenia. Diantara e-marketplace tersebut, penjualan melalui Tokopedia adalah yang paling banyak dibanding kedua lainnya. Perbedaan tersebut mungkin disebabkan oleh faktor desain, sistem keamanan, kemudahan penggunaan atau persepsi manfaat dari Tokopedia. Penelitian ini bertujuan untuk mengkaji faktor-faktor yang menentukan seseorang berniat menggunakan Tokopedia dalam berbelanja produk UKM agribisnis berbentuk cair dan gel. Penelitian ini juga menganalisis pola hubungan desain dan keamanan terhadap kemudahan penggunaan dan persepsi kemanfaatan. Di samping itu, untuk menganalisis kontribusi keamanan, kemudahan penggunaan dan persepsi manfaat terhadap niat penggunaan Tokopedia. Alat analisis data yang digunakan adalah structural equation modeling - partial least squares (SEM-PLS) yang disusun berdasarkan stimulus theoretical framework technologi acceptance model (STF-TAM). Penelitian dilaksanakan dengan melibatkan pengguna Tokopedia yang pernah berbelanja produk agribisnis pangan berbentuk cair dan gel. Data responden terkumpul sebanyak 71. Hasil penelitian menunjukkan bahwa kemudahan penggunaan merupakan faktor yang memiliki pengaruh yang paling besar diantara faktor lainnya. Faktor desain dan rancangan berpengaruh signifikan terhadap kemudahan penggunaan. Faktor Keamanan tidak berpengaruh signifikan terhadap niat penggunaan. Penemuan faktor dari niat penggunaan Tokopedia ini akan digunakan untuk membangun toko online Laurike.
\end{abstract}

Kata kunci: Toko Online Laurike, UKM, SEM-PLS, STF-TAM, Tokopedia

${ }^{1}$ Corresponding author:

Email: lufemanalu@gmail.com 


\section{INTRODUCTION}

Small and medium businesses (SMEs) play a vital role in realizing national development goals. They can also be considered as a locomotive of national and regional economic growth due to their potential to empower all available resources and encourage entrepreneurship development (Sari et al. 2016). However, SMEs in Indonesia still face various problems, including promotion, marketing, and product sales (Jauhari, 2010).

Microbusinesses in Indonesia still conduct their transactions conventionally, especially those in the agribusiness sector. According to the data from the Ministry of Communication and Information, only around 3.79 million (8\%) SMEs in Indonesia are using online platforms to market their products (Kemkominfo, 2017). Whereas the number of Indonesian online customers have reached 24.7 million people. So that, the involvement of SMEs digitally can increase economic growth by two percent.

Since 2011, the world has entered Industry 4.0, marked by increased connectivity, interaction, and boundaries between humans and machines and other resources. The number of internet users in Indonesia is increasing every year. According to a survey of the Indonesian Internet Service Providers Association (APJII), in 2017, the number of internet users in Indonesia has reached 143.26 million. Of the 2500 respondents, 32.19 percent used the internet to buy goods while only 8.12 percent to sell. Application-based online marketplaces, namely Tokopedia, Bukalapak, Lazada, and others, have been proven very useful for marketing since purchases of goods through e-commerce continue to rise. APJII (2018) surveyed internet use duration per day in 2017, involving 2500 respondents. The results showed that the respondents use the internet for 1-3 hours/day (43.89\%), 4-7 hours/day (29.63\%), and more than 7 hours/day (26.48\%). The fact that half of Indonesia's total population already uses the internet leads it to become one of the media to implement the most effective and efficient strategies in business and marketing.

Laurike Home Industry, or called Toko Laurike, is a member of the SMEs group where located in Bogor Regency. Toko Laurike produces Virgin Coconut Oil (VCO). They cooperates with other SMEs to sell agribusiness products. They not only sell their product but the other SMEs's product. The products are such as red ginger, fried onion, detergent, honey will be sold online. Offline marketing is done by opening a shop and join in an exhibition held by the Bogor Regency Government, SMESCO and Bogor Agricultural University's farm market.

Toko Laurike sells its products through several e-marketplaces, namely Tokopedia (https://www. tokopedia.com), Bukalapak (https://www.bukalapak. com), and Elevenia (http://www.elevenia.co.id). The level of sales varies significantly in each e-marketplace. In 2017, there were 7, 1, and 348 sales invoices through Bukalapak, Elevenia, and Tokopedia, respectively. It is worth reviewing why Toko Laurike VCO's products were sold more through Tokopedia than through the other two online markets. The products offered are the same: categorized as SMEs' food agribusiness products, having a short expiration time, and in the form of liquid and gel, which are damaged easily. Toko Laurike, as a business actor, must pay attention to what factors influence consumers in using Tokopedia. These differences are caused by several factors, like design, security system, perceived ease of use, or perceived usefulness of Tokopedia. Therefore, this study examined the factors that determine a person intending to use Tokopedia in shopping for liquid and gel agribusiness SME products need.

There were many types of research and models about the acceptance of information technology. Priyadi et al. (2017) analyzed the factors that influence digital office use (DiO) behavior at Bank XYZ with the Unified Theory of Acceptance and Use of Technology (UTAUT) model approach. TAM is a user acceptance model that is widely used by previous researchers with mixed findings (Willis, 2008; Park, 2009; Moeser et al. 2013; Erasmus et al. 2015; Indrayana et al. 2016; and Ula, 2018). Many studies have found that TAM is a model that consistently explains most of the variance in using goals and behavior, among a variety of technologies (Widiatmika and Sensuse, 2008). TAM was first developed by Davis (1989) in his doctoral research. TAM theorizes that a person's intention to use a system or technology determined by two factors (constructs), namely perceived ease of use and perceived usefulness. Perceived usefulness is the level of individual confidence that the use of technology will improve its performance. The definition of perceived ease of use is the level of confidence someone has that the system is easy to use (Devi and Suartana, 2014). 
Many researchers develop TAM, such as Venkatesh and Davis (2000), who developed the TAM2 model. The TAM 2 model consists of the original constructs of the TAM model, adds usage intention, and looks at the effect of perceived usefulness on usage intention by adding users' experience (Lai, 2017). Davis and Venkatesh provide a more detailed explanation related to the reasons for users in finding the usability of the system, which divided into three points of time, namely pre-implementation, one month after implementation, and three months after implementation (Lai, 2017).

Lai (2016) examined technology acceptance of a single e-payment system (merging cards, internet, and mobile into one system). Lai found the second model to be a stimulus for technology acceptance in the TAM2. This model is called the Stimulus Theoretical Framework Technology Acceptance Model (STF-TAM).

The STF-TAM technology acceptance model consists of Perceived Ease of Use, Perceived Usefulness, and Intention of Use. In STF-TAM, two factors stimulate a person's intention to use an application, seen from the features and capabilities of the system, which considered to motivate the use of the application. These two factors are Design and Security, which have a contribution to Perceived Ease of Use and Perceived Usefulness. Lai also stated that Security was proven to have a direct effect on a person's intention to use a single e-payment system. Design is the planning and function of a system, technically. Szymanski and Hise (2000) found that the ease of design on the site for online navigation would cause consumers to be more interested in making purchases and using E-payments. The influence of the use of e-commerce on the development of SMEs in Taiwan has studied regarding the impact on its business (Tseng, 2011). In Taiwan, SMEs actors who will enter the global market should be able to prepare themselves to use e-commerce. SMEs in Indonesia are also required to be able to utilize online shops or markets to increase their competitiveness and enter the global market.

For this reason, this study examined the factors that encourage someone to use Tokopedia for purchasing SMEs' food agribusiness products in liquid and gel form. This study aimed to find the determinants of the intention to use Tokopedia in shopping for SMEs' food agribusiness products in the form of liquid and gel such as VCO and others with the same characteristics. Other aims were to analyze the pattern of the correlation between Design and Security towards perceived ease of use and Perceived Usefulness and to analyze the contribution of Security to the intention to use Tokopedia. This study used the Stimulus Theoretical Framework Technology Acceptance Model developed by Lai (2016) and involved respondents who were Tokopedia users having shopped for SMEs food agribusiness products in the form of liquid and gel, including online customers at Toko Laurike. The results of the research would be input for Laurike Home Industry in developing e-commerce that is currently being studied. Other benefits of this research will also be input for agribusiness SMEs to take advantage of the market or online store as a marketing tool.

\section{METHODS}

This research was conducted in Jakarta for two months, September-October 2018. Data were collected through online questionnaires using Google Form by distributing the link via Whatsapp and Twitter. The target respondents were Tokopedia users that shopped at "Toko Laurike" in 2017 and shopped for agribusiness products in the forms of liquid and gel foods. The judgment or purposive method used as the sampling technique (Sumarwan et al. 2015) based on expertise on the subjects under study. According to Ghozali (2008), a small sample cause the parameters and statistical models unfavorable. PLS does not require many assumptions. Data do not need to be multivariate normally distributed. The sample does not have to be significant in number (Ghozali recommended 30100). The questionnaires collected in this study were 108 , but only 71 of which were valid or following the requirements.

In this study, the data were analyzed using Structural Equation Model-Partial Least Square (SEM-PLS), which can measure latent variables that cannot be measured directly with a small amount of data. Indicators were measured by asking the respondents to answer the questions using a Likert scale consisting of five items ranging from 1 , meaning very disagree, to 5 , meaning very agree. Correlations between variables obtained using SEM-PLS and descriptive analysis. According to Hair et al. (2006), an evaluation of the level of compatibility of the data with the model carried out in several stages, namely compatibility between all models, both the measurement and structural models. SEM-PLS involves the outer and inner models to 
evaluate. The outer or measurement model evaluation functions to assess the validity and reliability of indicators against the latent variables. Meanwhile, the inner or structural model evaluation aims to predict the causality relationship between latent variables through the bootstrapping process.

This study involved five latent variables (two exogenous and three endogenous), as showed in Table 1, including 21 variables as the indicators. All of them in the Table connected to be a path diagram model that shows the flow of correlations between endogenous and exogenous variables, as shown in Figure 1. Based on this diagram, the following eight hypotheses proposed according to the application carried out by Lai (2016) that showed that technology acceptance has two stimulating factors, namely Design and Security.
H1a : Design of Tokopedia is associated with Perceived Usefulness

H1b : Design of Tokopedia is associated with Perceived Ease of Use

$\mathrm{H} 2 \mathrm{a}$ : Security of Tokopedia is associated with Perceived Usefulness

$\mathrm{H} 2 \mathrm{~b}$ : Security of Tokopedia is associated with Perceived Ease of Use

$\mathrm{H} 2 \mathrm{c}$ : Security of Tokopedia is associated with Consumers' Intention to Use

H3 : Perceived Ease of Use of Tokopedia is associated with Perceived Usefulness

H4 : Perceived Ease of Use of Tokopedia is associated with Consumers' Intention to Use

H5 : Perceived Usefulness of Tokopedia is associated with Consumers' Intention to Use

Table 1. Operational definition of variables

\begin{tabular}{|c|c|c|c|}
\hline Latent Variable & Description (Indicator) & Symbol & Source \\
\hline \multicolumn{4}{|l|}{ Exogenous } \\
\hline \multirow[t]{3}{*}{ Design } & $\begin{array}{l}\text { Tokopedia has an exciting appearance, both in terms of menu or navi- } \\
\text { gation layout and color combinations }\end{array}$ & $\mathrm{X} 11$ & Lai (2016) \\
\hline & Tokopedia works fine, no errors & $\mathrm{X} 12$ & $\begin{array}{l}\text { Lin and Hsieh } \\
\text { (2006); Lai (2016) }\end{array}$ \\
\hline & No Repetition: Tokopedia can be accessed very quickly & $\mathrm{X} 13$ & Lai (2016) \\
\hline \multirow[t]{4}{*}{ Security } & Confidentiality: Tokopedia is safe from hackers or data theft & $\mathrm{X} 21$ & $\begin{array}{l}\text { Lai and Ahmad } \\
\text { (2015); Lai (2016) }\end{array}$ \\
\hline & $\begin{array}{l}\text { Authorization: Tokopedia is very trusted and protected by asking cus- } \\
\text { tomers to enter their user ID and password to access their account }\end{array}$ & $\mathrm{X} 22$ & Lai (2016) \\
\hline & Authentication: The Tokopedia application user data is highly secure & $\mathrm{X} 23$ & Lai (2016) \\
\hline & Reliability: No transaction errors occur due to application errors & $\mathrm{X} 24$ & Lai (2016) \\
\hline \multicolumn{4}{|l|}{ Endogenous } \\
\hline \multirow[t]{6}{*}{$\begin{array}{l}\text { Perceived } \\
\text { Ease of Use }\end{array}$} & Tokopedia is easy to use & Y11 & $\begin{array}{l}\text { Davis and } \\
\text { Venkatesh (2000); } \\
\text { Park (2009) }\end{array}$ \\
\hline & It is easy to register as a Tokopedia user & Y12 & $\begin{array}{l}\text { Park (2009); Lai } \\
\text { (2014) }\end{array}$ \\
\hline & It is easy for the users to activate their accounts & Y13 & Lai (2016) \\
\hline & $\begin{array}{l}\text { No long time is required to understand and operate the Tokopedia ap- } \\
\text { plication menu. }\end{array}$ & Y14 & $\begin{array}{l}\text { Davis and } \\
\text { Venkatesh (2000); } \\
\text { Park (2009); Lai } \\
\text { and Ahmad (2015); }\end{array}$ \\
\hline & Tokopedia can be used at anytime and anywhere & Y15 & Lai (2016) \\
\hline & Payment methods are very diverse and easy to use & Y16 & Lai (2016) \\
\hline
\end{tabular}


Table 1. Operational definition of variables (continuance)

\begin{tabular}{|c|c|c|c|}
\hline Latent Variable & Description (Indicator) & Symbol & Source \\
\hline \multirow[t]{5}{*}{$\begin{array}{l}\text { Perceived } \\
\text { Usefulness }\end{array}$} & Tokopedia makes customer free to find the product that it wants & Y21 & $\begin{array}{l}\text { Davis and } \\
\text { Venkatesh (2000) }\end{array}$ \\
\hline & Tokopedia helps in saving shopping time & Y22 & $\begin{array}{l}\text { Davis and } \\
\text { Venkatesh (2000); } \\
\text { Park (2009) }\end{array}$ \\
\hline & Tokopedia helps in saving energy in shopping & Y23 & $\begin{array}{l}\text { Lai and Ahmad } \\
\text { (2015); Davis } \\
\text { (1989) }\end{array}$ \\
\hline & Tokopedia allows respondent to trade anytime and anywhere & Y24 & $\begin{array}{l}\text { Lai and Zainal } \\
(2015)\end{array}$ \\
\hline & Tokopedia is safer for shopping online than other applications & Y25 & $\begin{array}{l}\text { Davis (1989); Lai } \\
\text { and Ahmad (2015) }\end{array}$ \\
\hline \multirow[t]{3}{*}{$\begin{array}{l}\text { Consumers' } \\
\text { Intention } \\
\text { to Use }\end{array}$} & I intend to use the Tokopedia application & Y31 & $\begin{array}{l}\text { Davis and } \\
\text { Venkatesh (2000); } \\
\text { Lai (2016) }\end{array}$ \\
\hline & $\begin{array}{l}\text { Every time I want to shop for agribusiness products in the forms of } \\
\text { liquid and gel, I will use Tokopedia }\end{array}$ & Y32 & $\begin{array}{l}\text { Davis and } \\
\text { Venkatesh (2000) }\end{array}$ \\
\hline & I intend to recommend others to use Tokopedia & Y33 & $\begin{array}{l}\text { Davis and } \\
\text { Venkatesh (2000) }\end{array}$ \\
\hline
\end{tabular}

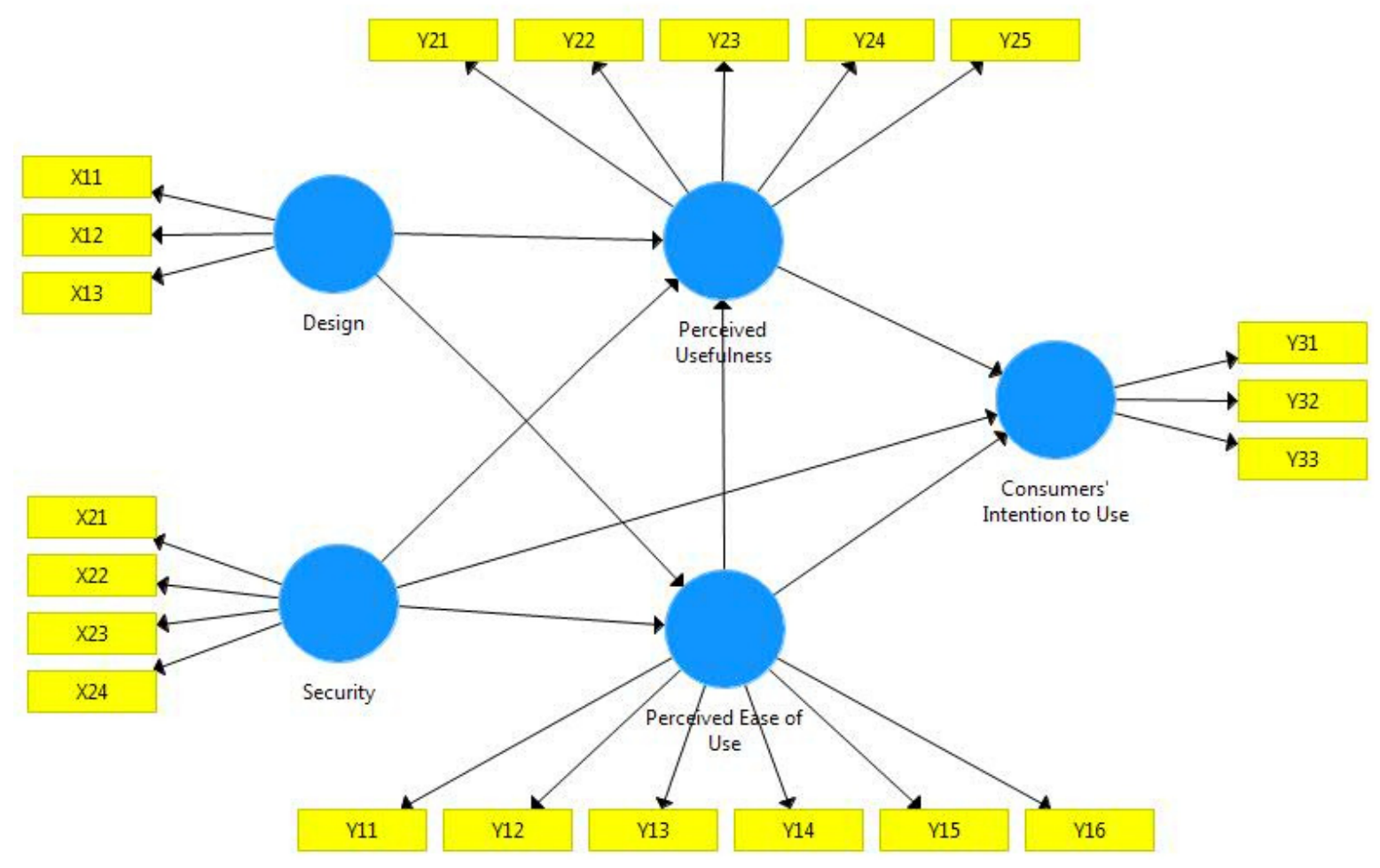

Figure 1. Research model to examine the determinants of the intention to use Tokopedia 


\section{RESULTS}

\section{Respondents' Characteristics}

Of the 108 questionnaires, only 71 were considered valid due to the requirement that the respondents must be users of Tokopedia who had already shopped for SMEs' food agribusiness products in the form of liquid and gel. Thirty respondents were users of Tokopedia but had never shopped for agribusiness products (food and beverage) in the forms of liquid and gel. The respondents' profiles in details provided in Table 2 based on demographic characteristics, namely age, sex, residence, education level, and occupation. The table illustrates that the frequency of shopping for SMEs food agribusiness products in the forms of liquid and gel is dominated by those who had made purchases more than once. However, more than half did not know Toko Laurike.
Respondent data were analyzed with the help of SmartPLS3 Software and using the guidelines set by Ringle et al. (2014). Outer models evaluated how the indicators reflect and represent the construct variables. All indicators in Table 1 were tested for validity and reliability, referring to the rule of thumb of Ghozali (2014). The results of the SEM-PLS analysis are present in Figure 2.

The convergent validity test is based on factor loading $(\lambda)>0.6$ and AVE $>0.5$, the discriminant validity test is on cross-loading $>0.7$, while the reliability test is on composite reliability $\left(\rho_{c}\right)$ and Cronbach's Alpha> 0.7 and has an average variance value extracted (AVE) and communality $>0.5$. The AVE, factor loading, and cross-loading values are present in Figure 3. The composite reliability $\left(\rho_{c}\right)$ and Cronbach's Alpha are in Table 3. Thus, all of them meet the requirements of analytical research. All indicators are valid and reliable in reflecting latent variables.

Table 2. Summary of respondents' characteristics in the study

\begin{tabular}{|c|c|c|c|}
\hline Characteristic & Respondent & Total & $\%$ \\
\hline \multirow[t]{2}{*}{ Sex } & Male & 37 & 52.1 \\
\hline & Female & 34 & 47.9 \\
\hline \multirow[t]{5}{*}{ Age of user } & $<20$ years & 3 & 4.23 \\
\hline & $21-30$ years & 42 & 59.15 \\
\hline & $31-40$ years & 14 & 19.72 \\
\hline & $41-50$ years & 9 & 12.68 \\
\hline & $>50$ years & 3 & 4.23 \\
\hline \multirow[t]{5}{*}{ Education } & Senior high school or equivalent & 7 & 9.86 \\
\hline & Diploma or equivalent & 7 & 9.86 \\
\hline & Bachelor degree (S1) & 50 & 70.42 \\
\hline & Master degree (S2) & 6 & 8.45 \\
\hline & Doctoral degree (S3) & 1 & 1.41 \\
\hline \multirow[t]{6}{*}{ Occupation } & Student & 7 & 9.86 \\
\hline & Civil servant/State-owned enterprise employee & 19 & 26.76 \\
\hline & Private employee & 25 & 35.21 \\
\hline & Entrepreneur & 14 & 19.72 \\
\hline & Housewife & 3 & 4.23 \\
\hline & Other & 3 & 4.23 \\
\hline \multirow{2}{*}{$\begin{array}{l}\text { Frequency of shopping for SMEs food } \\
\text { agribusiness products in the forms of liquid and } \\
\text { gel through Tokopedia }\end{array}$} & One & 23 & 32.39 \\
\hline & More than once & 48 & 67.61 \\
\hline \multirow[t]{2}{*}{ Ever shopped at Toko Laurike via Tokopedia } & Yes & 25 & 35.21 \\
\hline & No & 46 & 64.79 \\
\hline
\end{tabular}




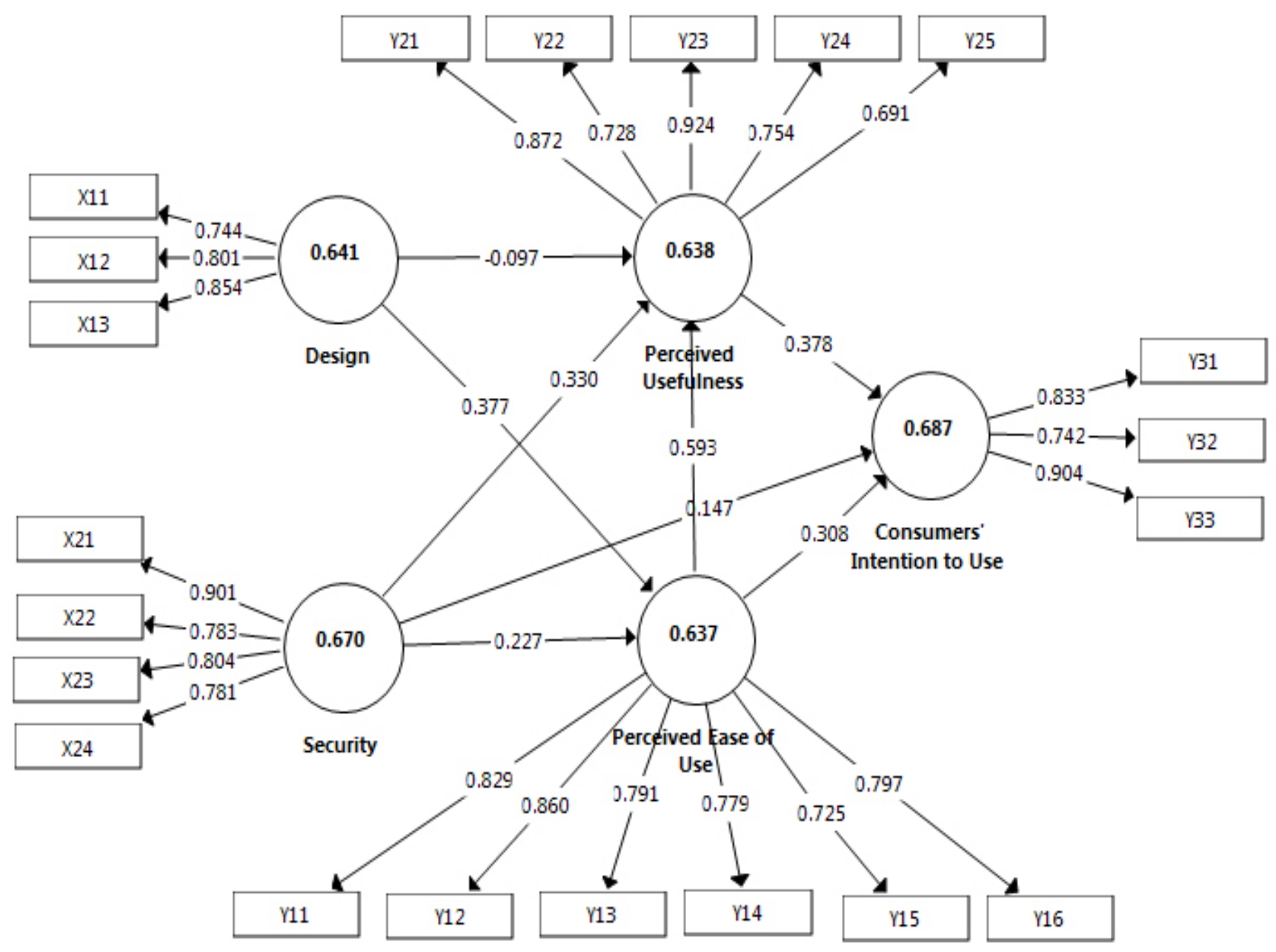

Figure 2. The standardized factor loading using PLS

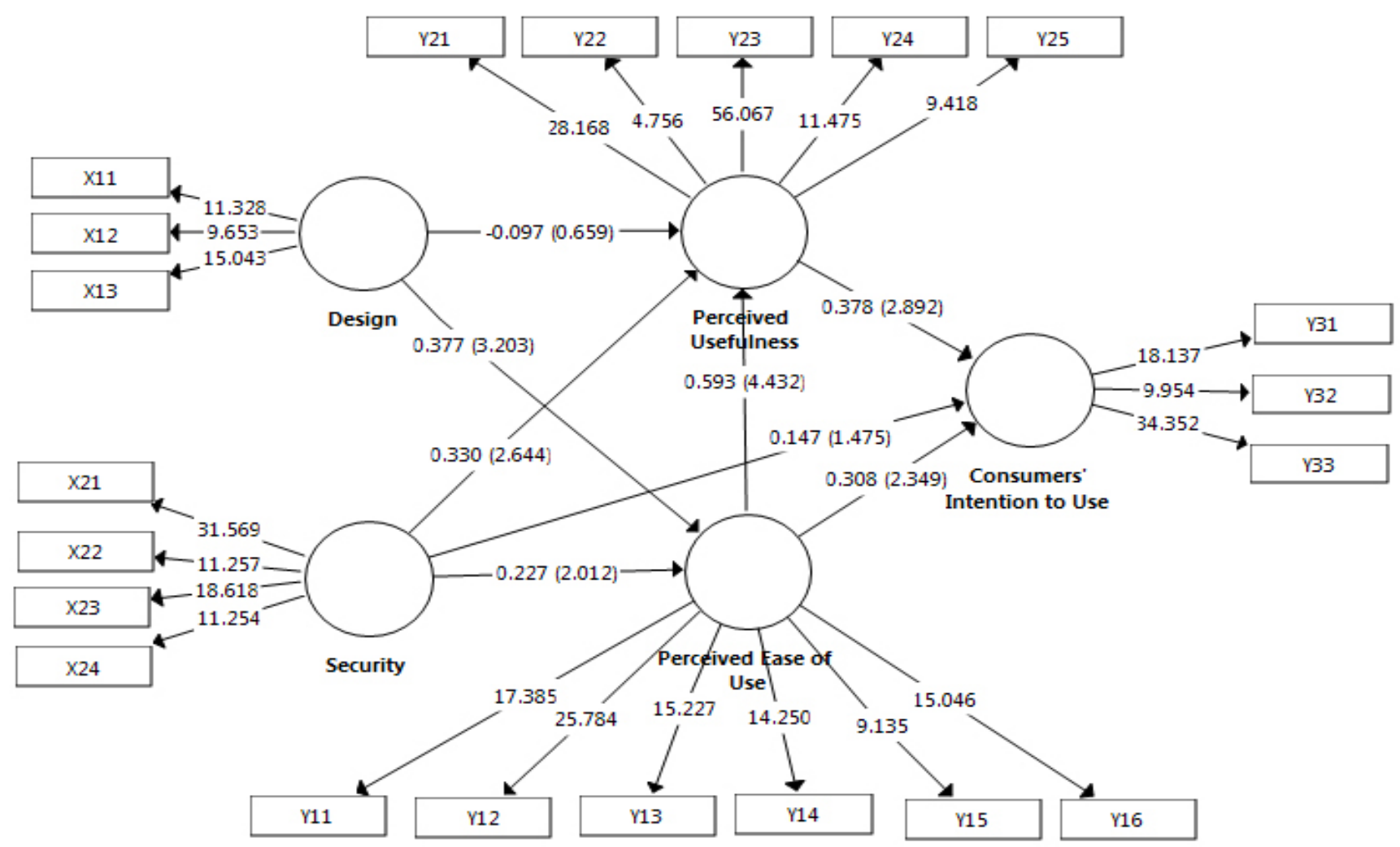

Figure 3. Bootstrapping results (path coefficient, T-Statistics, factor loading) 
Table 3. Values of AVE, Composite Reliability, Cronbach's Alpha, R-Square

\begin{tabular}{lcccc}
\hline Latent Variable & AVE & Composite Reliability & Cronbach's Alpha & R-Square \\
\hline Consumers' Intention To Use & 0.687 & 0.868 & 0.769 & 0.524 \\
Design & 0.641 & 0.843 & 0.721 & \\
Security & 0.670 & 0.890 & 0.835 & \\
Perceived Ease of Use & 0.637 & 0.913 & 0.885 & 0.301 \\
Perceived Usefulness & 0.638 & 0.897 & 0.855 & 0.551 \\
\hline
\end{tabular}

The factor loading value shows the relative contribution level of each indicator in the formation of the construct variables. In the variable Design, X13 (No Repetition) has the highest factor loading value, which is 0.854 , indicating that Tokopedia is considered easy to access. Meanwhile, in the Security factor, X21 (Confidentiality) has the highest value, which means that the Tokopedia security system is considered safe from hacker attacks. Y12 represents the highest indicator loading value on the Perceived Ease of Use factor (It is easy to register as a Tokopedia user). The highest indicator of the Perceived Usefulness factor is represented by Y23 (Tokopedia helps in saving energy in shopping). Lastly, the highest indicator of the Consumers' Intention to use factor by Y33 (Users recommend Tokopedia). These factor loading values also explain that all indicators have been able to reflect the construct variables by an average of above 70 percent.

The structural or inner models show the correlation between endogenous latent variables (Ghozali, 2014). The assessment of such structural models with PLS is considering the R-square value for each endogenous variable. Changes in the value of $\mathrm{R}$-square shows how much influence exogenous variables have on endogenous variables. The R-square values of each endogenous variable shown in Table 3.

Table 3 shows that the R-square value of Perceived Usefulness is 0.551 , meaning that the influence of the exogenous variables Design, Security, and Perceived Ease of Use is 55.1 percent, showing that the effect is moderate. The effect of Design and Security on Perceived Ease of Use is shallow at $30.1 \%$. Perceived Ease of Use, Perceived Usefulness, Design, and Security, simultaneously, affect on Consumers' Intention to Use as much as $52.4 \%$, meaning that the four variables are quite influential on one's intention to use Tokopedia to shop for agribusiness products in the forms of liquid and gel.
The effect magnitude or f-square also reflects structural model evaluation in PLS. If its value is 0.02 , then the effect of the predictor on the endogenous latent variable is low. The values of $\mathrm{f} 2$ of 0.15 and 0.35 stand for moderate and high effects, respectively. The highest value of $\mathrm{f} 2$ is of Perceived Ease of Use $\rightarrow$ Perceived Usefulness, namely 0.548 . Thus, in line with Lai's study (2016), ease of use has the most substantial influence on perceived usefulness. The lowest influence is of the variable Design on Perceived Usefulness, where the f-square value is 0.01 , meaning that the design of Tokopedia is not considered useful to the user. The second-highest $\mathrm{f} 2$ value is 0.141 , which is of Security on Perceived Usefulness. The second-lowest $\mathrm{f} 2$ value is of the correlation of Security $\rightarrow$ Consumers' Intention to Use, which is 0.031 .

Calculating the score of the observational value on the model and its indicator estimation employed by looking at the value of Q2. This value has the same meaning as the coefficient of determination (R-Square) in the regression analysis, where the higher the R-Square, the model can be said to be more fit to the data. Based on the R-square values in Table 3, Q2 values obtained as follows:

$$
\mathrm{Q} 2=1-(1-0.524) \times(1-0.301) \times(1-0.551)=0.850
$$

The value of Q2 of 0.850 indicates that the magnitude of the diversity of research data that can be explained by the structural model is 85 percent. This value indicates that the model has predictive relevance.

The assessment of the goodness of fit (GoF) for SEMPLS is different from that for CB-SEM. GoF aims to assess how good the SEM-PLS path model can explain different data sets (Tenenhaus et al. 2004). Calculating GoF on SEM-PLS is done manually using the root of the average AVE multiplied by the average R-square value. If the GoF value is 0.54 , then the structural model in this study already has a good GoF. Based on testing R2, Q2, and GoF, the research model is already robust. After evaluating the outer and inner models, to test the 
hypothesis, bootstrapping is performed with the help of SmartPLS3. Bootstrapping is an estimation technique that is carried out by repeated sampling (Jogiyanto, 2007).

A hypothesis is said to be influential if the t-statistics value is higher than the t-table. This study used a confidence level of $95 \%$ (alpha of 5 percent), so the $\mathrm{t}$-table value for the two-tailed hypothesis is $>1.99$. The value of t-statistics of $>1.99$ proves that six hypotheses in this study have a significant effect, while the two others have not. The results of hypothesis testing are present in Table 4.

\section{Testing the Correlation between Variables Based on the Research Hypotheses}

The testing of the eight hypotheses proposed in this study carried out by evaluating the value of the path coefficient. If the value is negative, it will be considered not to have a direct effect, but through other constructs. Six hypotheses found to have a significant effect, namely $\mathrm{H} 1 \mathrm{a}, \mathrm{H} 2 \mathrm{a}, \mathrm{H} 2 \mathrm{~b}, \mathrm{H} 3, \mathrm{H} 4$, and H5, while the other two did not, namely $\mathrm{H} 1 \mathrm{~b}$ and $\mathrm{H} 2 \mathrm{c}$. Based on theoretical results and empirical support, the latent variables Design and Security affect the Perceived Ease of Use. Security has a significant effect on Perceived Usefulness, which is in line with Lai's research (2016).
Design does not have a significant effect on Perceived Usefulness, nor does Security contribute directly to Consumers' Intention to Use. The results of our test were different from those of Lai's research (2016), where both Design and Security contribute or have a significant influence on Perceived Ease of Use and Perceived Usefulness. Lai (2016) also argued that Security has a direct contribution to the Intention to Use of the Single Payment application. Different in the model of the acceptance of Tokopedia's intention to use, the reliable security of the system considered not directly to influence someone intending to use Tokopedia.

Perceived Ease of Use found to have significant effect on Perceived Usefulness, in line with what was found by Willis (2008); Park (2009); Moeser et al. (2013); Erasmus et al. (2015); Indrayana et al. (2016), and Ula (2018).

Perceived Ease of Use and Perceived Usefulness significantly affect Consumers' Intention to Use. The results of this study are in line with Lai (2016), that the ease of use influences user perception of the usefulness. The easier Tokopedia to use considered to be beneficial for users.

Table 4. Hypothesis testing results

\begin{tabular}{lccc}
\hline Hypothesis & $\begin{array}{c}\text { Path } \\
\text { coefficient }\end{array}$ & T- Statistics $>1.99$ & Conclusion \\
\hline $\begin{array}{l}\text { H1a: Design of Tokopedia affects Perceived } \\
\text { Usefulness }\end{array}$ & 0.377 & 3.203 & Affects Significantly \\
$\begin{array}{l}\text { H1b: Design of Tokopedia affects Perceived Ease } \\
\text { of Use }\end{array}$ & -0.097 & 0.659 & Does not affect Significantly \\
$\begin{array}{l}\text { H2a: Security of Tokopedia affects Perceived } \\
\text { Usefulness }\end{array}$ & 0.227 & 2.012 & Affects Significantly \\
$\begin{array}{l}\text { H2b: Security of Tokopedia affects Perceived Ease } \\
\text { of Use }\end{array}$ & 0.330 & 2.644 & Affects Significantly \\
$\begin{array}{l}\text { H2c: Security of Tokopedia affects Consumers' } \\
\text { Intention to Use }\end{array}$ & 0.147 & 1.475 & Does not affect Significantly \\
$\begin{array}{l}\text { H3: Perceived Ease of Use of Tokopedia affects } \\
\text { Perceived Usefulness }\end{array}$ & 0.593 & 4.432 & Affects Significantly \\
$\begin{array}{l}\text { H4: Perceived Ease of Use of Tokopedia affects } \\
\text { Consumers' Intention to Use }\end{array}$ & 0.308 & 2.349 & Affects Significantly \\
$\begin{array}{l}\text { H5: Perceived Usefulness of Tokopedia affects } \\
\text { Consumers' Intention to Use }\end{array}$ & 0.378 & 2.892 & Affects Significantly \\
\hline
\end{tabular}

Note: table $\alpha=5 \%$ or 0.05 (1.99) for the two-tailed hypothesis test 
Based on the results of bootstrapping, the highest total value of influence on Consumers' Intention to Use is of the variable Perceived Ease of Use that is equal to 0.533 , meaning that ease of use affects the intention to use Tokopedia by 53.3 percent. The ease of use determines someone's intention to use Tokopedia.

\section{Managerial Implications}

Toko Laurike can utilize these findings to build its online store by taking into account the ease of use of the application. Ease of use of this application will convince users that the online store is useful for their lives. Also, the attractiveness of the designs and reliable security systems must be kept in mind.

The presence of online shops expected to increase competitiveness in similar sectors and be able to side with MSME actors who already have branding in the online market. The results of this research gave input to agribusiness SMEs that the online market had to be a marketing tool. Seeing that the Tokopedia application was also in demand by users to shop for agribusiness products that were difficult to pack, which were liquid. The hope of taking advantage of online stores or markets invites every SME actor to use an online platform.

\section{CONCLUSIONS AND RECOMMENDATIONS}

\section{Conclusions}

The results showed that ease of use is the factor that has the most influence than Design, Security, and Perceived Usefulness, based on the total value of the direct effect of the Perceived Ease of Use.

Design has a significant effect on perceived ease of use, given that the $t$-statistic value is higher than the $t$-table and the path coefficient. Security has a direct effect on Perceived Usefulness. Different from hypothesis H1b, Design has no significant effect on Perceived Usefulness, meaning an attractive design considered not to affect the perceived benefits of the system significantly. This statement is different from the theoretical model developed by Lai (2016), revealing that Design and Security have a significant influence on Perceived Usefulness.
Security does not significantly influence or does not contribute to the intention to use Tokopedia (Consumers' Intention to Use), which is also different from the theoretical model developed by Lai (2016), saying that Security gives a significant influence on Consumers' Intention to Use).

\section{Recommendations}

The results showed that respondents who made purchases more than once through Tokopedia had more than those who made only once. Thus, further research can add the variable Experience to see the technology acceptance model. We suggest that future studies gather a more significant number of respondents for the sake of model consistency. Large amounts of data can be processed using more complex model analyzing tools to see the correlation value between exogenous variables in the model.

\section{REFERENCES}

[APJII] Asosiasi Penyelenggara Jasa Internet Indonesia. 2017. Hasil Survei Penetrasi dan Perilaku Pengguna Internet Indonesia 2017.https://www. apjii.or.id/content/read/39/342/Hasil-SurveiPenetrasi-dan-Perilaku-Pengguna-InternetIndonesia-2017 [2019 Jan 28].

[APJII] Asosiasi Penyelenggara Jasa Internet Indonesia. 2018. Potre zaman now pengguna dan perilaku internet Indonesia.https://apjii.or.id/downfile/ file/BULETINAPJIIEDISI23 Apri12018. pdf[2018 Des 27].

Davis FD. 1989. Perceived usefulness, perceived ease of use, and user acceptance of information technology. MIS Quarterly 13(3):319-340. https://doi.org/10.2307/249008.

Erasmus E, Rothmann S, VanEeden C. 2015. A structural model of technology acceptance. SA Journal of Industrial Psychology 41(1):12-22. https://doi.org/10.4102/sajip.v41i1.1222.

Jauhari J. 2010. Upaya pengembangan usaha kecil dan menengah (UKM) dengan memanfaatkan e-commerce. Jurnal Sistem Informasi (JSI) Ilmu Komputer Universitas Sriwijaya 2(1):159-168.

Jogiyanto H. M. 2007. Model Kesuksesan Sistem Teknologi Informasi. Yogyakarta: Andi Offset.

Ghozali I. 2008. Structural Equation Modeling Metode Alternatif dengan Partial Least Square Ed ke-2. Semarang: BP-Undip. 
Ghozali I. 2014. Structural Equation Modeling, Metode Alternatif dengan Partial Least Square (PLS) Dilengkapi software Smartpls 3.0 Xlstat 2014 dan WarpPLS 4.0 Ed ke-4. Semarang: Universitas Diponegoro Semarang.

Hair JF, Anderson RE, Tatham RL, Black WC. 2006. Multivariate Data Analysis. 8th Ed. Upper Saddler River, New York: Prentice-Hall, Inc

Indrayana B, Seminar KB, Sartono B. 2016. Faktor Penentu Minat Penggunaan Instagram untuk Pembelian Online Menggunakan Technology Acceptance Model (TAM) dan Theory of Planned Behavior (TPB). Jurnal Aplikasi Bisnis dan Manajemen 2(2):138-147. https://doi. org/10.17358/JABM.2.2.138.

[KEMKOMINFO] Kementerian Komunikasi dan Informatika RI. 2017. Kemenkop UKM: 3,79 Juta UMKM Sudah Go Online. https://www. kominfo.go.id/content/detail/11526/kemenkopukm-379-juta-umkm-sudah-go-online/0/ sorotan_media [2017 Apr 27].

Lai PC, Ahmad ZA. 2015. Perceived Enjoyment of Malaysian consumers' intention to use a single platform E-payment. Di dalam: $S H S$ Web of Conferences. editor. Proceedings of International Conference on Liberal Arts \& Social Sciences. France (FR): EDP Sciences. hlm 1-9; [2018 Des 1]. https://doi.org/10.1051/ shsconf $/ 20151801009$

Lai PC. 2016. Design and security impact on consumers' intention to use single platform e-payment. Interdisciplinary Information Sciences 22(1): 111-122. https://doi.org/10.4036/iis.2016.R.05.

Lai PC. 2017. The Literature Review of Technology Adoption Models and Theories for The Novelty Technology. JISTEM - Journal of Information Systems and Technology Management 14 (1): 2138. doi: 10.4301/S1807-17752017000100002.

Lin J, Hsieh P. 2006. The role of technology readiness in customers' perception and adoption of selfservice technologies. International Journal of Service Industry Management 17(5):497-517. https://doi.org/10.1108/09564230610689795.

Moeser G, Moryson H, Schwenk G. 2013. Determinants of online social business network usage behavior - applying the technology acceptance model and its extensions. Journal of Psychology Scientific Research (SciRes) 4(4):433-437. http://dx.doi. org/10.4236/psych.2013.4406.
Park SY. 2009. An analysis of the technology acceptance model in understanding university students' behavioral intention to use e-learning. educational technology \& society. International Forum of Educational Technology \& Society (IFETS) 12 (3):150-162.

Priyadi R, Daryanto A, Hermadi I. 2017. Perilaku penggunaan portal E-office di Bank XYZ dengan pendekatan model UTAUT. Jurnal Aplikasi Bisnis dan Manajemen 3(2):185-195. doi: 10.17358/JABM.3.2.185

Ringle CM, Silva DD, Bido D. 2014. Structural Equation Modeling With The Smartpls. Brazilian Journal of Marketing - BJM 13(2):56-73. http://dx.doi. org/10.5585/remark.v13i2.2717.

Sari NM, Suwarsinah H, Baga LM. 2016. Pengaruh karakteristik kewirausahaan terhadap kinerja usaha mikro, kecil dan menengah (UMKM) Gula Aren di Kabupaten Lombok Barat. Jurnal Penyuluhan 12(1):51-60. http://dx.doi. org/10.25015/penyuluhan.v12i1.11320.

Szymanski DM, Hise R. 2000. E-satisfaction: an initial examination. Journal of Retailing 76(3):309-322. https://doi.org/10.1016/S00224359(00)00035-X.

Tenenhaus M, Amato S, Esposito VV. 2004. A global goodness-of-fit index for PLS structural equation modelling. In: Proceedings of the XLII SIS scientific meeting. pp 739-742.

Tseng. 2011. Factors affecting the use of e-commerce in the global market by small and medium enterprises in Taiwan [dissertation]. USA: University of Maryland. College Park (USA).

Ula RRM. 2018. Faktor yang mempengaruhi minat mahasiswa untuk membeli barang secara online [tesis]. Bogor: Institut Pertanian Bogor.

Venkatesh V, Davis FD. 2000. A theoretical extension of the technology acceptance model: Four longitudinal field studies. Management Science 46:186-204. https://doi.org/10.1287/ mnsc.46.2.186.11926.

Widiatmika IMAA, Sensuse DI. 2008. Pengembangan model penerimaan Internet oleh menggunakan teknologi pelajar konsep dengan technology acceptance model. Jurnal Sistem Informasi MTI-UI 4(2):81-92. https://doi.org/10.21609/ jsi.v4i2.249.

Willis TJ. 2008. An evaluation of the technology acceptance model as a means of understanding online social networking behavior [dissertation]. Tampa: University of South Florida. 